\section{New Trends and Issues Proceedings on Humanities and Social Sciences}

Volume 6, Issue 2 (2019) 37-49
'New Trends and Issues Proceedings on Humanities and Social Sciences

www.prosoc.eu

Selected Paper of 8th World Conference on Business, Economics and Management (BEM-2019) 26 - 28 April 2019, Grand Park Lara Hotel Convention Center, Antalya, Turkey

\title{
Career engagement of different generations: A case study in the information and communication technology (ICT) sector in Lithuania
}

Gita Statnicke*, Kaunas University of Technology, K. Donelaicio st. 73, LT-44029 Kaunas, Lithuania Asta Savaneviciene, Kaunas University of Technology, K. Donelaicio st. 73, LT-44029 Kaunas, Lithuania Ignas Sakys, Kaunas University of Technology, K. Donelaicio st. 73, LT-44029 Kaunas, Lithuania

\section{Suggested Citation:}

Statnicke, G., Savaneviciene, A. \& Sakys, I. (2019). Career engagement of different generations: A case study in the information and communication technology (ICT) sector in Lithuania. New Trends and Issues Proceedings on Humanities and Social Sciences. [Online]. 6(2), pp 37-49. Available from: www.prosoc.eu

Selection and peer review under responsibility of Prof.Dr. Cetin Bektas, Gaziosmanpasa University, Turkey. ${ }^{\circ} 2019$ United World Center of Research Innovation and Publication. All rights reserved.

\begin{abstract}
The aim of this article is to analyse career engagement of different generations in the Information and Communication Technology (ICT) sector in Lithuania. The research is based on the Kaleidoscope Career Model and Career Engagement Scale. The research included 571 representatives of Generation X and Generation Y living in Lithuania, EU, and those working in the ICT sector and/or studying in the area of Informatics. The Pearson correlation analysis and Independent Samples $t$ Test were used for data analysis. The research revealed that career engagement of Generation X in the ICT sector is higher than that of Generation $Y$ and is influenced by a variety of socio-demographic and other factors. The dimensions of the Kaleidoscope Career Model-Authenticity, Balance and Challenge-and their need are more vividly expressed in Generation $\mathrm{X}$ than in Generation $\mathrm{Y}$. Statistically significant differences were identified in career engagement of generations $\mathrm{X}$ and $\mathrm{Y}$ and Balance and Challenge dimensions of the Kaleidoscope Career Model.
\end{abstract}

Keywords: Career engagement, different generations, Generation X, Generation Y information and communication technology (ICT) sector.

\footnotetext{
* ADDRESS FOR CORRESPONDENCE: Gita Statnicke, Kaunas University of Technology, K. Donelaicio st. 73, LT-44029 Kaunas, Lithuania. E-mail address: gita.statnicke@ktu.edu
} 
Statnicke, G., Savaneviciene, A. \& Sakys, I. (2019). Career engagement of different generations: A case study in the information and communication technology (ICT) sector in Lithuania. New Trends and Issues Proceedings on Humanities and Social Sciences. [Online]. 6(2), pp 37-49. Available from: www.prosoc.eu

\section{Introduction}

Rapidly improving technologies and the characteristics of new generations of employees entering the labour market, as well as their attitude to career, pose new challenges to the Human Resources management specialists (Kultalahti \& Viitala, 2015) and the researchers of the field. Based on Europe's Digital Progress Report, Lithuania ranks 13th out of the 28 EU Member States in the European Commission Digital Economy and Society Index (DESI) (2017). Lithuania's DESI score is above the EU average, i.e., Lithuania performs particularly well in Connectivity and Integration of Digital Technology, but Lithuania is below the EU average for Human Capital in the Information and Communication Technology Sector (2017). According to Eurostat, the specialists of the Information and Communication Technology (ICT) sector in Lithuania comprise $2.7 \%$ of the total labour force, which is a smaller part of the workforce than the EU average amounting to 3.7\%. Unfortunately, this number has not increased in Lithuania in recent years the way the demand for such specialists has increased. An increasing problem of shortage of the ICT sector employees in Lithuania encourages employers to seek new staff management solutions on how to attract talents and retain the existing employees. The employers' attitude to the employees is gradually changing, especially taking into consideration the fact that the labour market has been integrating the youngest employees of Generation Y (Stanimir, 2015), who are particularly sensitive to work and personal life balance as well as to good physical and emotional well-being. In addition, the ICT sector, dominated by global practices and tendencies, gets under pressure due to the fact that employees are highly mobile, not loyal to the company and often tend to change their workplaces - these are the characteristics of the representatives of Generation $Y$ (Clark, 2017; Zhang, Lu \& Kizildag, 2017), who are gradually taking higher positions in the labour market and significantly differ from the employees of Generation X in the ICT sector. This article aims at providing theoretical aspects of a career and career engagement in the context of different generations, identifying the Kaleidoscope Career Model (KCM) in the context of different generations, carrying out the overview of the ICT sector in Lithuania, and identifying how career engagement differs across generations $\mathrm{X}$ and $\mathrm{Y}$ and what significant differences there are between career engagement and three dimensions of the Kaleidoscope Career Model-Authenticity, Balance and Challenge.

\section{Theoretical aspects of a career and career engagement in the context of different generations}

A career is often seen as one of the main human goals (Vondracek, Lerner \& Schulenberg, 2018), as it ensures human self-actualisation opportunities, social status and consequential material guarantees, as well as determines employee satisfaction with work (Lepold, Tanzer, Bregenzer \& Jimenez, 2018) and life in general. Generational differences determine different career needs of individuals who belong to these generations ( $\mathrm{Ng}$, Lyons \& Schweitzer, 2018). A career of an individual in a professional life consists of career stages (Lepojevic, Djordjevic \& Ivanovic-Djukic, 2018), which are influenced by personal values, responsibility, different activities and different approaches (Twenge, 2010), behaviour and other components (Teng, Jayasingam \& Zain, 2018; Twenge, Campbell, Hoffman \& Lance, 2010), often described in scientific literature exploring various aspects of generations as generational differences at work (Cucina, Byle, Martin, Peyton \& Gast, 2018; Holian, 2015; Jones, Murray \& Tapp, 2018; Rudolph \& Zacher, 2018). It is observed that the employees belonging to different generations have different career development tasks, goals and other characteristics defining career, including career engagement. Hirschi, Freund and Herrmann (2014, p. 3 ) define career engagement 'as the degree to which somebody is proactively developing his or her career as expressed by diverse career behaviours', and indicate that 'career engagement refers 1) to and directly measures the general degree of being engaged in different career management behaviours; 2) not to attitudes but to the specific career behaviours somebody exhibits to enhance her or his career development and 3 ) does not directly refer to self-management strategies and behaviours but instead addresses overt career behaviours more generally' and 'career engagement addresses the current interest in proactive career behaviours to describe contemporary career 
Statnicke, G., Savaneviciene, A. \& Sakys, I. (2019). Career engagement of different generations: A case study in the information and communication technology (ICT) sector in Lithuania. New Trends and Issues Proceedings on Humanities and Social Sciences. [Online]. 6(2), pp 37-49. Available from: www.prosoc.eu

development'. This article analyses career engagement of two generations: Generation X, born between 1965 and 1979 (Alonderiene, Fuchs, Pilkaite \& Pilkienè, 2017), and Generation Y (also known as the Millennials), born between 1980 and 2000 (Deyoe \& Fox, 2012; Hillman, 2014).

Generation $X$ requires a clear career plan and defined opportunities to pursue career goals. In pursuit of a career, Generation X seeks for material reward and good teamwork (Teng, et al., 2018) since Generation $X$ stands out for the need to cooperate with the representatives of other generations. Robbins (2002) suggests that Generation X is characterised by loyalty to their career rather than to their organisation. Generation X, unlike the representatives of Generation $Y$, do not think they are unique; however, they seek new skills to use towards new opportunities, and they tend to have more diverse directional changes in their careers (Chuang, 2019). Generation $X$ is defined as socially active, life balanced and emotionally happy employees who pursue continuing education (Miller, 2011). Although Generation $X$ is superior to Generation $Y$ in their experience and the already well-formed useful personal relations, however, seeking for more active career engagement of the representatives of Generation $X$, they could learn higher technical skills and ambitiousness from Generation Y.

As for Generation $Y$, the key formative characteristic is early and frequent exposure to technology (Bolton et al., 2013; Immordino-Yang, Christodoulou \& Singh, 2012). In scientific literature, in terms of Generation $\mathrm{Y}$, six features are distinguished: the ability to do a variety of tasks, the desire for structure, result orientation, technological insights, focus on the team and seeking for attention and feedback (Farrell \& Hurt, 2014). Generation $Y$ is considered the most tech-savvy of the current generations in the workplace (Zhang, Abound Omran \& Cobanoglu, 2017). Information and Communication Technology is constantly evolving and Generation Y, more than any other generation in the workforce, can quickly pick up new technology and master it. Generation $Y$ creates a dynamic work environment because these employees have a tendency to improve services, processes and orientation to constant personal growth. Frequently, there are discussions on how to retain the employees of Generation $Y$ longer, because long-term experience and competence is of importance in the ICT sector companies, and since Generation $\mathrm{Y}$ is characterised by loyalty to the employer (Stanimir, 2015), their enhanced career engagement is noticeable only as long as they see career opportunities and feel continuous feedback from their managers (Naim \& Lenka, 2018). As for Generation Y, development of personal competence, experience and obvious results are of significance in career and promote their career engagement.

Career engagement of Generation $Y$ poses more challenges than career engagement of Generation $X$ due to the former's high self-esteem and high expectations (Tulgan, 2009) and their reluctance to put wholehearted efforts into less meaningful work (Alsop, 2008) just for a career. Due to these reasons, the engagement of some of the representatives of Generation $Y$ is very low, especially in the absence of interesting activities (Alsop, 2008; Hartman \& McCambridge, 2011). Generation Y sees no clear dividing line between work and pleasure, so for greater career engagement of this generation, work should be interesting and fun (Schullery, 2013; Tapscott, 2009). Moreover, in order to promote career engagement, the representatives of Generation $Y$ need to learn cooperation with other generations.

Career engagement of the representatives of both generations $X$ and $Y$ is complicated by the fact that a professional career in the ICT sector ranges from highly technical to requiring good business awareness. Careers in the ICT sector deal with the design, creation, management and maintenance of a variety of components of the system, including software, hardware, networks, systems integration, multimedia and other, i.e., in order to enhance the performance of these functions, greater career engagement is required. Career engagement of Generation $Y$ and Generation X in the ICT sector is a very important part of their professional development. 
Statnicke, G., Savaneviciene, A. \& Sakys, I. (2019). Career engagement of different generations: A case study in the information and communication technology (ICT) sector in Lithuania. New Trends and Issues Proceedings on Humanities and Social Sciences. [Online]. 6(2), pp 37-49. Available from: www.prosoc.eu

\section{The KCM in the Context Different Generations}

One of the newest models - the KCM, highlights a career as an important part of individual's life. A kaleidoscope is used metaphorically in this conception. Individuals evaluate their needs and opportunities as if looking through a kaleidoscope in order to determine the most appropriate combination among different aspects of work, as well as relationships, personal values and interests. This is to emphasise that when one part moves, even if it is not very significant, the arrangement of all other parts changes accordingly, i.e., one decision affects the entire kaleidoscopic career structure. A personal life and career are highly related, thus whenever taking any career or personal life decisions, it is necessary to assess their impact on other areas. The authors of the Model suggest that modern career cannot be considered unconstrained. There are always constraints, but now some of them have to be recognised and set individually. Mainiero and Sullivan (2011) relate constraints to three main parts that have an impact on the individual's career: 1) authenticity, which is perceived as being loyal to oneself, one's values, beliefs when individuals seek for careers that would meet their needs. This parameter also shows how individual's internal values correspond to their external behaviour and relate to the values of the organisation; 2) balance, which describes individual's decisions related to work and personal life so that they formed a unity, i.e., work-life balance and 3) challenge is a human goal for independence and responsibility as well as learning, skills development and personal growth. Challenge also implies an individual's desire for career heights and the use of different opportunities. Challenge may include aspects related to personal life, but the KCM focuses on challenges in the work environment (Grady \& McCarthy, 2008; Mainiero \& Sullivan, 2011).

All the three parts of the Kaleidoscope Career Model change depending on the priority for an individual in a specific stage of life. When changing one part, the entire structure of the model changes (Grady \& McCarthy, 2008). If one becomes more active, other two dimensions become less intense and distance away but they are still active since all aspects are important and necessary for the creation of an individual's new career model (Sullivan, Forret, Carraher \& Mainiero, 2008). The values of this career model include life-work balance, social responsibility to do good work and challenges of learning new things continuously. A career is self-directed, i.e., created depending on individual choices, and how it will continue to develop depends exclusively on the individual.

The Kaleidoscope Career Model was used in the research to analyse generational differences. Sullivan, Forret, Carraher and Mainiero (2009), applying the KCM examined generational differences in terms of the attitude to work, i.e., they researched how the Baby Boom generation and Generation $\mathrm{X}$ differ in their needs for authenticity, balance and challenge. The research results show that the employees of Generation X are sensitive to the need for authenticity and balance more than the employees of the Baby Boom generation. The authors assume that in order to meet different generational needs, it is necessary to adapt to human resources management practices.

It is very important for Generation $Y$ that personal values matched the organisational values and their work was significant (Alsop, 2008). To have a healthy working relationship, it is necessary to enable employees to fulfil both career and personal goals. When both sets of goals are fulfilled, employees are likely to stay longer since their self-actualisation has been achieved (Teng et al., 2018). From the leadership and management perspectives, members of Generation $Y$ want to be seen as individuals as well as being respected, valued and heard by their supervisors (Kultalahti \& Viitala, 2015; Rentz, 2015). Dries, Pepermans and De Kerpel (2008) identified differences between beliefs about career success and satisfaction with respect to different generations, i.e., with regard to importance attached to organisational security, Generation $Y$ scored significantly higher than Generation X. Career development training for Generation $X$ and $Y$ managers will increase job satisfaction and retention ( $D^{\prime}$ Amato \& Herzfeldt, 2008). To improve job satisfaction in Generation $X$ and $Y$, organisations can offer flexible scheduling, expansion of recognition programmes, increased career development opportunities and more decision-making autonomy (Wilson, Squires, Widger, Cranley \& Tourangeau, 2008). Balance is important for both of these generations: they will sacrifice 
Statnicke, G., Savaneviciene, A. \& Sakys, I. (2019). Career engagement of different generations: A case study in the information and communication technology (ICT) sector in Lithuania. New Trends and Issues Proceedings on Humanities and Social Sciences. [Online]. 6(2), pp 37-49. Available from: www.prosoc.eu

balance, but only occasionally; applicable only to Generation Y. They value their lifestyle over upward mobility, i.e., if presented with promotion at work that will throw their life out of balance, they will choose their lifestyle (Valentine \& Powers, 2013).

The KCM was also used to identify employees' needs in a global mobile career, which is absolutely relevant to the employees of all generations working in the ICT sector. It was found that the needs in terms of mobile career in different stages of life differ (Kirk, 2016). To reduce the mismatch of needs, the researchers propose to impellent mentoring and other human resources management programmes.

\section{An overview of the ICT sector in Lithuania}

Pursuant to the Regulation (EC) No. 251/2009 of the Commission of the European Communities, the ICT sector includes institutional units, the activities of which, according to the Classification of Economic Activities (2nd Rev.), are as follows: ICT manufacturing [manufacture of electronic components and boards (26.1); manufacture of computer and peripheral equipment (26.2); manufacture of communication equipment (26.3); manufacture of consumer electronics (26.4); manufacture of magnetic and optical media (26.8)]; ICT service [software publishing (58.2); telecommunications (61); computer programming, consultancy and related activities (62); data processing, hosting and related activities; web portals (63.1); repair of computers and communication equipment (95.1)]; ICT trade [wholesale of information and communication equipment (46.5)].

ICT sector in Lithuania is growing and gradually gaining more attention from foreign investors. Based on the data provided by the Lithuanian Department of Statistics (2018), at the end of 2017, cumulative foreign direct investment (FDI) in the ICT sector totalled 1.11 billion EUR or $7.5 \%$ of the total FDI in Lithuania. The main foreign investors in this sector include Sweden-612.8 million EUR (55\% of the total FDI in the ICT sector), the Netherlands-323.6 million EUR (29\%), the United Kingdom-34.3 million EUR, Latvia-23.9 million EUR and Germany-23.5 million EUR.

The analysis of the data of the Lithuanian Department of Statistics (2018) shows that there were 6,459 ICT enterprises in Lithuania in 2017. As provided in Table 1, the main structural business statistics on the ICT sector grew during the period 2013-2017.

As Table 1 shows, in 2017, the number of individuals employed in ICT enterprises amounted to 35,014 . Compared to 2016 , this figure increased by $3.8 \%$ and made up $3.3 \%$ of the total number of individuals employed (in 2016, 3.3\%).

Table 1. Main structural business statistics on the ICT sector, 2013-2017 (data of the Lithuanian Department of Statistics, 2018)

\begin{tabular}{cccccccc}
\hline Year & $\begin{array}{c}\text { Number of } \\
\text { enterprises }\end{array}$ & $\begin{array}{c}\text { Number } \\
\text { of } \\
\text { persons } \\
\text { employed }\end{array}$ & $\begin{array}{c}\text { Number of } \\
\text { employees }\end{array}$ & $\begin{array}{c}\text { Turnover, } \\
\text { EUR } \\
\text { million }\end{array}$ & $\begin{array}{c}\text { Personnel } \\
\text { costs, } \\
\text { EUR } \\
\text { million }\end{array}$ & $\begin{array}{c}\text { Value } \\
\text { added at } \\
\text { factor } \\
\text { costs, EUR } \\
\text { million }\end{array}$ & $\begin{array}{c}\text { Gross } \\
\text { investment } \\
\text { in tangible } \\
\text { assets, EUR } \\
\text { million }\end{array}$ \\
\hline 2013 & 3,818 & 26,867 & 25,642 & 2,442 & 416 & 755 & 133 \\
2014 & 5,127 & 29,410 & 27,437 & 2,608 & 463 & 850 & 134 \\
2015 & 5,758 & 31,630 & 29,286 & 3,096 & 533 & 986 & 133 \\
2016 & 6,097 & 33,738 & 31,222 & 3,305 & 611 & 1,031 & 153 \\
$2017^{*}$ & 6,459 & 35,014 & 32,229 & 3,871 & 691 & 1,137 & 149 \\
\hline
\end{tabular}

*Provisional data.

The number of individuals employed increased in all ICT sectors: in ICT service by $3.1 \%$, in ICT wholesale by $1.6 \%$ and in ICT manufacturing by $20.8 \%$. An increase in the number of individuals employed in ICT service was observed in computer programming, consultancy and related activities 
Statnicke, G., Savaneviciene, A. \& Sakys, I. (2019). Career engagement of different generations: A case study in the information and communication technology (ICT) sector in Lithuania. New Trends and Issues Proceedings on Humanities and Social Sciences. [Online]. 6(2), pp 37-49. Available from: www.prosoc.eu

(4.8\%), and in data processing, hosting and related activities; web portals (12\%). The number of individuals employed in ICT manufacturing increased almost three times (from 132 to 363 individuals employed) in the manufacture of computers and peripheral equipment activities (Lithuanian Department of Statistics, 2018).

In 2017, among individuals employed in the ICT sector, individuals aged 25-54 years prevailed and accounted for $80.4 \%$ of all individuals employed in the ICT sector. The employed individuals under 25 years of age accounted for $12.5 \%$, and over 55 years of age $-7.1 \%$. The majority of ICT specialists in Lithuania have high educational attainment. In 2017, the majority (78.9\%) of individuals employed in the ICT sector had high educational attainment (high educational attainment level-higher, postsecondary tertiary education), those with medium educational attainment (medium-general lower secondary with vocational qualification, general upper secondary, general upper secondary with vocational qualification, special secondary) accounted for $21.1 \%$.

Based on the overview of the data provided by the Lithuanian Department of Statistics regarding the ICT sector in Lithuania, it can be assumed that this sector is constantly growing, engaging middleaged (Generations $\mathrm{Y}$ and $\mathrm{X}$ ) and high-education employees, and consequently resulting in the demand for new ICT specialists, which highlights the relevance of career engagement in the ICT sector.

\section{Research methodology}

Based on the analysed theoretical aspects of a career and career engagement in the context of different generations, provided in the KCM in the context of different generations, and the overview of the Information and Communication Technology (ICT) sector in Lithuania, the main research question has been formulated: how does career engagement differ across generations $X$ and $Y$ ? The following research hypotheses have been raised:

H1: There is a statistically significant difference between Generation $\mathrm{X}$ and Generation $\mathrm{Y}$ when evaluating career engagement and the dimensions of the Kaleidoscope Career Model-Authenticity, Balance and Challenge.

$\mathrm{H} 2$ : The dimensions of the Kaleidoscope Career Model-Authenticity, Balance and Challenge-have influence on/correlate with career engagement of different generations $\mathrm{X}$ and $\mathrm{Y}$.

Quantitative research was carried out in January-March 2019 in Lithuania, EU. To implement the purpose and to collect information and data, a quantitative research method-a questionnaire, was applied. According to Kardelis (2007), in terms of management, quantitative research is more accurate since it can cover more research subjects which reflect the opinion of the majority. The most appropriate and commonly used quantitative data collection method is a questionnaire survey. In order to engage Generation X in the survey, an invitation to participate in the survey, including the reference to the online questionnaire, was sent to all companies of the ICT sector in Lithuania; to engage the participation of Generation $\mathrm{Y}$-to all the higher education institutions of Lithuania that have a study programme in the area of Informatics. All the respondents participated in the survey on a voluntary basis, ensuring their anonymity and personal data protection.

The Instrument. When forming the research instrument, in order to determine career engagement of generations $X$ and $Y$, the first part of the questionnaire included the concept of career engagement provided by Hirschi et al. (2014), and the Career Engagement Scale. The Scale consists of nine statements that need to be evaluated using five-point Likert-type items (1-almost never; 2occasionally; 3-a moderate amount; 4-quite often; 5-very often). The Career Engagement Scale indicated good internal consistency (Cronbach's alpha) for the total sample (0.88) (Hirschi et al., 2014); in the research, Cronbach Alpha was calculated-0.89. The second part of the questionnaire included the KCM and the questionnaire formed by Sullivan et al. (2009), which measured three KCM parameters-authenticity, balance and challenge. The questionnaire consists of 15 statements (five for each parameter), which have to be evaluated on the five-point Likert-type scale (1-this does not 
Statnicke, G., Savaneviciene, A. \& Sakys, I. (2019). Career engagement of different generations: A case study in the information and communication technology (ICT) sector in Lithuania. New Trends and Issues Proceedings on Humanities and Social Sciences. [Online]. 6(2), pp 37-49. Available from: www.prosoc.eu

describe me at all and 5-this describes me very well). To verify the reliability of the Kaleidoscope Career Model questionnaire, an increased reliability Cronbach Alpha coefficient was calculated, which revealed that this methodology is reliable-Cronbach Alpha coefficient is 0.823 . To determine the respondents' characteristics, the questionnaire includes eight questions related to gender, age, education, study programme (for students), marital status, the length of work experience in the ICT sector, the company type of the ICT sector and the position held. The nominal scale was used for these questions.

The Sample. The research included 571 representatives of different generations $X$ and $Y$ living in Lithuania, EU, and working in the ICT sector and/or studying in the area of Informatics. The respondents were assigned to generations based on their date of birth: Generation X, born between 1965 and 1979 (Alonderiene, Fuchs, Pilkaite \& Pilkiene, 2017), and Generation Y, born between 1980 and 2000 (Deyoe \& Fox, 2012; Hillman, 2014).

The Demographic Characteristics of the Sample. The research included 571 questionnaires which subjected to analysis: $13.66 \%$ of the sample $(n=78)$ included females; the other $86.34 \%(n=493)$ were males. According to the date of birth, the respondents were attributed to two different generations: $50.96 \%$ to the Generation X $(n=291)$ and $49.04 \%$ to the Generation $Y(n=280)$.

According to their educational attainment level, the respondents have distributed as follows: high educational attainment level (ISCED 5.6) was indicated by $65.15 \%(n=372)$ of the respondents, 83.16\% $(n=242)$ of which comprised Generation $X$ and $46.43 \%(n=130)$ comprised Generation $Y$; medium educational attainment level (ISCED 3.4) was indicated by $34.85 \%(n=199)$ of the respondents, $16.84 \%(n=49)$ of which comprised the representatives of Generation $X$ and $53.57 \%(n=$ 150) of Generation Y. Out of 571 respondents who participated in the research, $76.36 \%(n=436)$ worked in the ICT sector, $23.64 \%(n=135)$ studied in the ICT study programmes. $20.49 \%(n=117)$ of the respondents indicated that they worked in the ICT sector and studied in the ICT study programmes. About $48.21 \%(n=135)$ of Generation $Y$ who participated in the survey were studying in the ICT area at the time of research; $41.79 \%(n=117)$ worked and studied in the ICT area; $10 \%(n=28)$ of the representatives of Generation $Y$ indicated that they only worked. All the respondents of Generation $X$ indicated that they worked in the ICT sector, i.e., none of the representatives of this generation was studying in ICT study programmes at the time of research.

The major part of respondents $-88.53 \%(n=386)$ work in the ICT service enterprise, $1.15 \%(n=5)$ work in the ICT manufacturing enterprise, $6.42 \%(n=28)$ work in the ICT wholesale enterprise; $3.9 \%(n$ $=17$ ) selected the option 'other'. Thus, according to the data of 2017 of the Department of Statistics of the Republic of Lithuania, this corresponds to the following distribution of enterprises in the ICT sector in Lithuania: $88.9 \%$ in the ICT service enterprises, $1.1 \%$ in the ICT manufacturing enterprises, $6.3 \%$ in the ICT wholesale enterprises; and $3.7 \%$ in the telecommunications enterprises. About $42.14 \%$ ( $n=118$ ) of the representatives of Generation $Y$ indicated that they did not have work experience/work record in the ICT sector, $48.93 \%(n=137)$ of the representatives of Generation $X$ indicated that the length of work experience in the ICT sector was $1-5$ years; $6.43 \%(n=18)$ indicated that their length of work experience was $6-10$ years; $2.5 \%(n=7)$ indicated as $11-15$ years. About $40.21 \%(n=117)$ indicated that the length of work experience in the ICT sector was $11-15$ years and $59.79 \%(n=174)$ indicated that it was over 15 years.

The data obtained from the research were analysed by the statistical software package SPSS 22.0. Two methods were used for data analysis: the Pearson correlation analysis and Independent Samples $t$-Test.

\section{Results and discussions}

To determine if there is a significant difference between different generations $X$ and $Y$ when analysing the selected variables (career engagement and the dimensions of the Kaleidoscope Career 
Statnicke, G., Savaneviciene, A. \& Sakys, I. (2019). Career engagement of different generations: A case study in the information and communication technology (ICT) sector in Lithuania. New Trends and Issues Proceedings on Humanities and Social Sciences. [Online]. 6(2), pp 37-49. Available from: www.prosoc.eu

Model-Authenticity, Balance and Challenge), one of the most popular statistical criteria (statistics)Student's $t$-test (Independent Samples $t$-Test) -was applied.

Table 2 provides Group Statistics. As Table 2 shows, the means of values of career engagement and the dimensions of the Kaleidoscope Career Model-Authenticity, Balance and Challenge-are higher in Generation X (Career engagement is $M=3.90$, Authenticity is $M=3.84$, Balance is $M=3.76$ and Challenge is $M=3.88$, respectively) than the means of values of Generation $Y$ (Career engagement is $M=3.48$, Authenticity is $M=3.73$, Balance is $M=3.53$ and Challenge is $M=3.58$, respectively).

Table 2. Group statistics

\begin{tabular}{lcccccc}
\hline & \multicolumn{2}{c}{ Generation $\mathbf{Y}(\boldsymbol{N}=\mathbf{2 8 0})$} & \multicolumn{3}{c}{ Generation $\mathbf{X}(\boldsymbol{N}=\mathbf{2 9 1})$} \\
& Mean & $\begin{array}{c}\text { Std. } \\
\text { deviation }\end{array}$ & $\begin{array}{c}\text { Std. error } \\
\text { mean }\end{array}$ & Mean & $\begin{array}{c}\text { Std. } \\
\text { deviation }\end{array}$ & $\begin{array}{c}\text { Std. error } \\
\text { mean }\end{array}$ \\
\hline Career_engagement & 3.4817 & 0.82599 & 0.04936 & 3.9030 & 0.79430 & 0.04656 \\
KCM_Authenticity & 3.7343 & 0.75137 & 0.04490 & 3.8433 & 0.91300 & 0.05352 \\
KCM_Balance & 3.5250 & 0.74791 & 0.04470 & 3.7615 & 0.81429 & 0.04773 \\
KCM_Challenge & 3.5779 & 0.79799 & 0.04769 & 3.8811 & 0.52340 & 0.03068 \\
\hline
\end{tabular}

Gender has influence on career engagement: career engagement is higher among women of Generation $Y$ (the mean of values of career engagement of Generation $Y$ males is 3.45, and of Generation $Y$ females is 3.86, respectively; the mean of values of career engagement of Generation $X$ males is 3.95, and of Generation X females is 3.72). Marital status has more influence on Generation $\mathrm{Y}$-the ones married or living with a partner $(M=3.36)$ are more engaged in career than those living alone or being divorced $(M=3.86)$; while marital status does not have such influence on Generation $X$ (living alone or being divorced is $M=3.89$; married or living with a partner is $M=3.91$, respectively). Educational attainment level has influence on career engagement: career engagement of Generation $X$ respondents with high educational attainment level is the highest (the mean of values of career engagement of Generation $Y$ respondents with high educational attainment level is 3.63, and of Generation $Y$ respondents with medium educational attainment is 3.35 , respectively; the mean of values of career engagement of Generation X respondents with high educational attainment level is 4.09, and of Generation $X$ respondents with medium educational attainment is 3.00 ). The representatives of Generation $\mathrm{Y}$ who work in the ICT sector and study in the ICT study programme are more engaged in career $(M=3.77)$ than those who only work in the ICT sector $(M=3.52)$ or only study $(M=3.22)$. The ones without work experience/work record are less engaged in career than those with work experience in the ICT sector (the mean of values of career engagement of Generation $Y$ representatives without work experience/work record in the ICT sector is 3.16; when work record in the ICT sector is $1-5$ years, the mean of values is 3.7 ; when it is $6-10$ years -3.78 ; $11-15$ years -3.84 ; the mean of values of career engagement of Generation X representatives with work record of 11-15 years in the ICT sector is 3.92; with work record over 15 years is 3.89). The representatives of Generation $Y$ who are mostly engaged in career are employed in ICT wholesale companies $(M=3.7)$ and ICT service companies $(M=3.74)$, while the representatives of Generation $X$-in the ICT sector $(M=5)$.

The analysis of the dimensions of the Kaleidoscope Career Model shows that the highest mean of values of Generation $Y$ is in the Authenticity sub-scale $(M=3.73)$, while the dimension of Balance is expressed least $(M=3.52)$. For Generation $Y$, Authenticity in terms of career is the most important of the three dimensions of the Model, since the representatives of this generation are most willing to improve, to perform the meaningful activity and to pursue their dreams and goals. This confirms the discussions provided in the theoretical part regarding the attitude of Generation $Y$ to career (Tulgan, 2009), the reluctance of Generation $Y$ to put efforts into less meaningful work (Alsop, 2008) just for a career; and low engagement of Generation $Y$ in career in the absence of interesting activities (Alsop, 2008; Hartman \& McCambridge, 2011). 
Statnicke, G., Savaneviciene, A. \& Sakys, I. (2019). Career engagement of different generations: A case study in the information and communication technology (ICT) sector in Lithuania. New Trends and Issues Proceedings on Humanities and Social Sciences. [Online]. 6(2), pp 37-49. Available from: $\underline{\text { www.prosoc.eu }}$

Meanwhile, for Generation $X$, the most important dimension is Challenge $(M=3.88)$. According to Bejtkovsky (2016), Generation $X$ is oriented to career development opportunities, and this is also confirmed by the research findings, i.e., for Generation $X$, challenges at work and career orientation are of importance, while the dimensions of Authenticity $(M=3.84)$ and Balance $(M=3.76)$ are expressed slightly less significantly. This means that it is important for the respondents of both generations to reconcile their career and personal life so that they did not interfere with each other; it is expressed least significantly in the sample.

The Independent Samples $t$-Test requires the assumption of homogeneity of variance, i.e., both groups have the same variance. SPSS conveniently includes a test for the homogeneity of variance, called Levene's Test (Levene's Test for Equality of Variances). Based on Levene's criterion (Table 3), it was determined that the dispersions of the group Career_engagement can be considered equal, since career engagement $p$-value $>\alpha(0.051>0.05$ when significance level is $\alpha=0.05)$. All three dimensions of the Kaleidoscope Career Model (Authenticity, Balance and Challenge) show the following result: $p<$ $\alpha(0.000<0.05 ; 0.021<0.05$ and $0.000<0.05$, respectively), so we assume that group dispersions are not equal, and while verifying the hypothesis, we will analyse the lines Equal variances not assumed. Verifying the raised hypothesis, we will take into account the found $p$-value which is provided in the column Sig. (2-tailed). Since Career engagement and two dimensions of the Kaleidoscope Career Model (Balance and Challenge) display Sig. (2-tailed) $p$-value that is less than $\alpha(0.00<0.05)$, it can be concluded that the means of indicators of Career engagement and two dimensions of the Kaleidoscope Career Model-Balance and Challenge-statistically significantly differ between generations $\mathrm{X}$ and $\mathrm{Y}$ (Hypothesis $\mathrm{H} 1$ is partially confirmed). Hence, the probability that the existing difference of means can be explained by accidence is equal to 0 , because $p$-value is 0 . As for the dimension of Authenticity of the Kaleidoscope Career Model, it was found that the differences of the means of this indicator are statistically insignificant between generations $X$ and $Y$ since the $p$-value is higher than $\alpha(0.121>0.05)$.

Table 3. Calculations by Student's $t$-test (independent samples $t$-test) for the variable career engagement and the dimensions of authenticity, balance and challenge of the Kaleidoscope Career Model

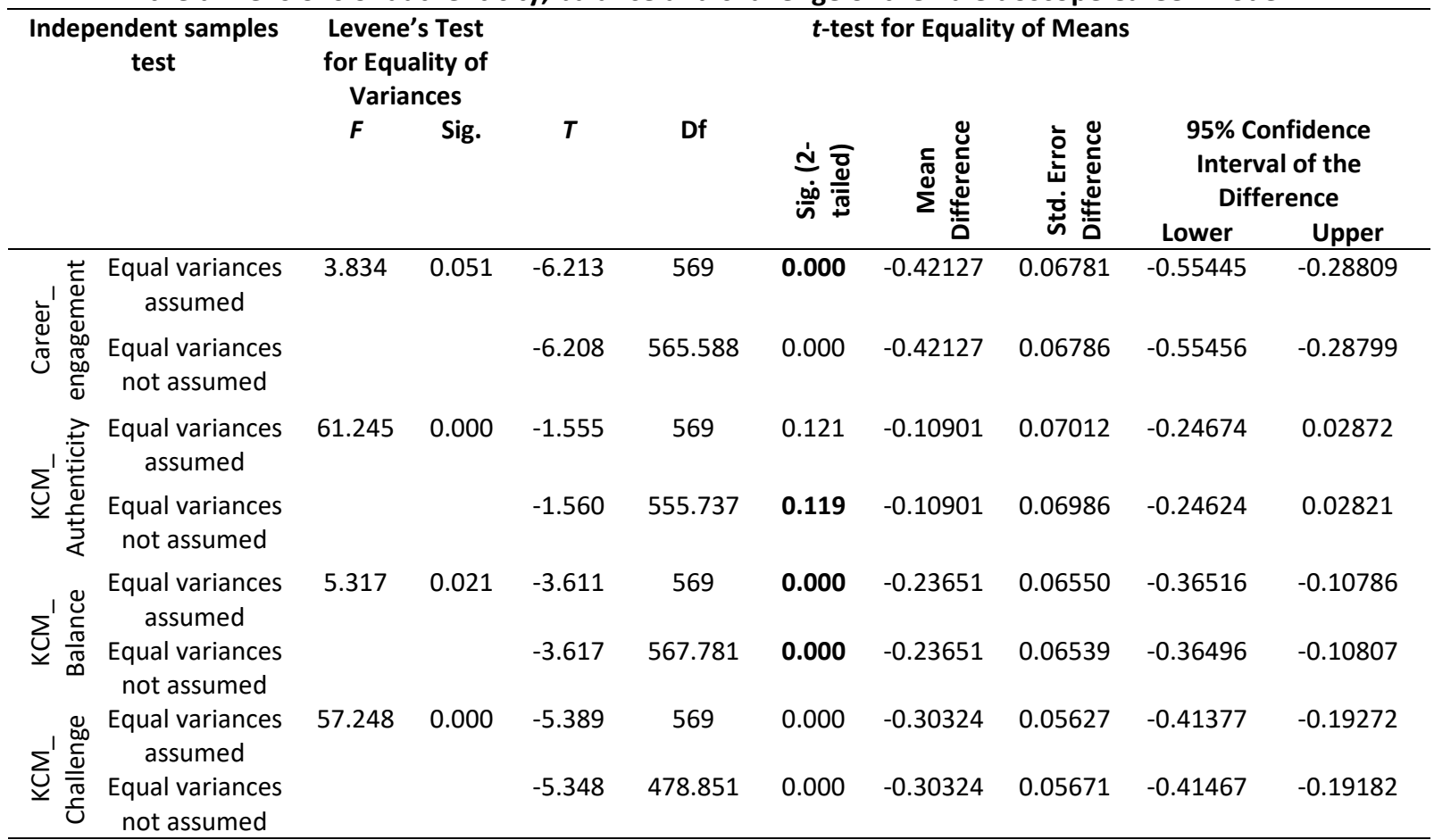


Statnicke, G., Savaneviciene, A. \& Sakys, I. (2019). Career engagement of different generations: A case study in the information and communication technology (ICT) sector in Lithuania. New Trends and Issues Proceedings on Humanities and Social Sciences. [Online]. 6(2), pp 37-49. Available from: $\underline{w w w . p r o s o c . e u}$

The slight difference (see Table 3 above) can be of accidental nature. The probability that the difference is of accidental nature is equal to $12.1 \%$. The statistically significant differences between career engagement and two dimensions of the Kaleidoscope Career Model obtained during the research confirm the statements found in the scientific literature about the differences between generations $X$ and $Y$ in career (Kong, Wang \& Fu, 2015; Ng et al., 2018).

To determine how three dimensions of the Kaleidoscope Career Model-Authenticity, Balance and Challenge-influence career engagement of different generations $X$ and $Y$, the Pearson correlation analysis has been performed. As Table 4 shows, career engagement of the representatives of Generation Y correlates with the indicator of Authenticity; the correlation between them is linear, and although weak (only 0.293), it is statistically significant. Career engagement of the representatives of Generation Y correlates with the indicator of Challenge; the correlation between them is linear and of moderate strength (0.607), and it is also statistically significant. Based on the obtained data, career engagement of Generation $Y$ does not correlate with Balance. The analysis of Generation X shows that career engagement correlates with Authenticity and Challenge much stronger, but it does not correlate with Balance, as it was in the case of Generation Y. In Generation X, the correlation between Career engagement and Authenticity is linear and very strong (correlation coefficient is 0.803 ). The correlation coefficient between career engagement and Challenge among the representatives of Generation $X$ is also positive (correlation coefficient is 0.604 ), which shows a linear moderate dependence between these variables. In conclusion, we can assume that by increasing the indicators of Authenticity and Challenge in both generations, career engagement of the representatives of both generations also increases. This partially confirms the hypothesis $\mathrm{H} 2$, i.e., the dimensions of the Kaleidoscope Career Model-Authenticity, Balance and Challenge-have influence on/correlate with career engagement of generations $\mathrm{X}$ and $\mathrm{Y}$.

Table 4. The Pearson Correlations of Generation $X$ and Generation $Y$

\begin{tabular}{|c|c|c|c|c|c|c|c|}
\hline \multicolumn{2}{|c|}{ Correlations } & \multicolumn{3}{|c|}{ Generation $Y(N=280)$} & \multicolumn{3}{|c|}{ Generation X $(N=291)$} \\
\hline & & $\begin{array}{c}\text { KCM_Authe } \\
\text { nticity }\end{array}$ & $\begin{array}{c}\text { KCM_Bal } \\
\text { ance }\end{array}$ & $\begin{array}{c}\text { KCM_Chall } \\
\text { enge }\end{array}$ & $\begin{array}{c}\text { KCM_Authen } \\
\text { ticity }\end{array}$ & $\begin{array}{c}\text { KCM_Bal } \\
\text { ance }\end{array}$ & $\begin{array}{c}\text { KCM_Chall } \\
\text { enge }\end{array}$ \\
\hline \multirow{2}{*}{ 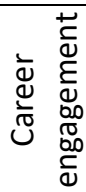 } & $\begin{array}{c}\text { Pearson } \\
\text { Correlation }\end{array}$ & $0.293^{* *}$ & 0.016 & $0.607^{* *}$ & $0.803^{* *}$ & -0.032 & $0.604^{* *}$ \\
\hline & $\begin{array}{l}\text { Sig. (2- } \\
\text { tailed) }\end{array}$ & 0.000 & 0.785 & 0.000 & 0.000 & 0.591 & 0.000 \\
\hline
\end{tabular}

According to Mainiero and Sullivan (2011), authenticity is perceived as being loyal to oneself, one's own values, beliefs when individuals are in pursuit of careers that meet their needs; hence, the increase of this indicator directly influences career engagement. This is in line with Westerman and Yamamura's (2007) findings, who found that if the goals of the representatives of generations $X$ and $Y$ meet the goals of the organisation they work for, the representatives of both generations tend to stay in the organisation and feel more satisfied. Challenge is also important for career engagement of both generations in the ICT sector-this is the pursuit for individual's independence and responsibility, learning, skills development and personality growth; and the individual's desire to pursue career heights (Grady \& McCarthy, 2008; Mainiero \& Sullivan, 2011) as the ICT sector is the sector of continuous change, learning and development (Heeks \& Stanforth, 2015).

\section{Conclusions}

The generalised analysis of scientific literature and research findings lead to the following conclusions: 
Statnicke, G., Savaneviciene, A. \& Sakys, I. (2019). Career engagement of different generations: A case study in the information and communication technology (ICT) sector in Lithuania. New Trends and Issues Proceedings on Humanities and Social Sciences. [Online]. 6(2), pp 37-49. Available from: $\underline{w w w . p r o s o c . e u}$

Career engagement of the representatives of Generation $X$ in the ICT sector is higher than that of Generation Y. Career engagement is influenced by a variety of socio-demographic and other factors: gender (career engagement is higher among women of Generation Y); marital status (the representatives of Generation $Y$ who are married or living with a partner are more engaged in career than those living alone or being divorced); educational attainment level (career engagement of the respondents of Generation $X$ with high educational attainment level is the highest); work-studies (the representatives of Generation Y who work in the ICT sector and study in the ICT study programmes are more engaged in career than those who only work in the ICT sector or only study); the length of work experience (those with no work record are less engaged in career than those with work record in the ICT sector); the type of company (the representatives of Generation $Y$ who are mostly engaged in career work in ICT wholesale companies and ICT service companies, while those of Generation X-in ICT sector).

The dimensions of the Kaleidoscope Career Model-Authenticity, Balance and Challenge-and their need are more vividly expressed in Generation X than in Generation Y. For Generation Y, Authenticity in terms of career is the most important of all three components of the Model, since the representatives of this generation are most eager to develop, to perform the meaningful activity and to pursue their dreams and goals. Meanwhile, for Generation X, the dimension of Challenge is the most important, i.e., for Generation X, challenges at work and career orientation are of importance, while the dimensions of Authenticity and Balance are less vividly expressed.

There were statistically significant differences identified between career engagement of generations $\mathrm{X}$ and $\mathrm{Y}$ and two dimensions of the Kaleidoscope Career Model-Balance and Challenge. Two dimensions of the Kaleidoscope Career Model-Authenticity and Challenge-have an influence on/statistically significantly correlate with career engagement of different generations $X$ and $Y$. By increasing the indicators of Authenticity and Challenge in both generations, career engagement of the representatives of both generations also increases; therefore, in order to ensure successful cooperation between generations $X$ and $Y$ and to increase career engagement of both generations in the ICT sector workplace, it is recommended to take into account two dimensions of the Kaleidoscope Career Model-Authenticity (especially for Generation X) and Challenge.

\section{References}

Alonderienè, R., Fuchs, J., Pilkaitè, M. \& Pilkienè, M. (2017). Workaholism and individual work performance in Lithuanian and German financial sector multinational corporations: differences between generations $X$ and Y. In Intercultural interactions in the multicultural workplace. Cham, Switzerland: Springer, Cham. doi:10.1007/978-3-319-39771-9_14

Alsop, R. (2008). The trophy kids grow up: How the millennial generation is shaking up the workplace. Hoboken, NJ: John Wiley \& Sons.

Bejtkovsky, J. (2016). The employees of baby boomers generation, generation $X$, generation $Y$ and generation $Z$ in selected Czech corporations as conceivers of development and competitiveness in their corporation. Journal of Competitiveness, 8(4), 105-123. doi:10.7441/joc.2016.04.07

Bolton, R. N., Parasuraman, A., Hoefnagels, A., Migchels, N., Kabadayi, S., Gruber, T., ... Solnet, D. (2013). Understanding Generation $Y$ and their use of social media: a review and research agenda. Journal of Service Management, 24(3), 245-267. doi.org/10.1108/09564231311326987

Chuang, S. (2019). Generation Xers' performance and development in midlife transition. Human Resource Development International, 22(1), 101-112. doi:10.1080/13678868.2018.1440130

Clark, K. R. (2017). Managing multiple generations in the workplace. Radiologic technology, 88(4), 379-396.

Cucina, J. M., Byle, K. A., Martin, N. R., Peyton, S. T. \& Gast, I. F. (2018). Generational differences in workplace attitudes and job satisfaction: Lack of sizable differences across cohorts. Journal of Managerial Psychology, 33(3), 246-264. doi:10.1108/JMP-03-2017-0115 
Statnicke, G., Savaneviciene, A. \& Sakys, I. (2019). Career engagement of different generations: A case study in the information and communication technology (ICT) sector in Lithuania. New Trends and Issues Proceedings on Humanities and Social Sciences. [Online]. 6(2), pp 37-49. Available from: www.prosoc.eu

D'Amato, A. \& Herzfeldt, R. (2008). Learning orientation, organizational commitment and talent retention across generations: a study of European managers. Journal of Managerial Psychology, 23(8), 929-953. https://doi.org/10.1108/02683940810904402

Deyoe, R. H. \& Fox, T. L. (2012). Identifying strategies to minimize workplace conflict due to generational differences. Journal of Behavioral Studies in Business, 5, 1-27.

Dries, N., Pepermans, R. \& De Kerpel, E. (2008). Exploring four generations' beliefs about career: Is "satisfied" the new "successful"?. Journal of managerial Psychology, 23(8), 907-928. doi:10.1108/ 02683940810904394

Europe's Digital Progress Report (EDPR) (2017). Europe's Digital Progress Report (EDPR) 2017, Country Profile Lithuania. Retrieved from https://ec.europa.eu/digital-single-market/en/desi

Farrell, L. \& Hurt, A. C. (2014). Training the millennial generation: implications for organizational climate. $E$ Journal of Organizational Learning \& Leadership, 12(1), 1-14.

Grady, G. \& McCarthy, A. M. (2008). Work-life integration: Experiences of mid-career professional working mothers. Journal of Managerial Psychology, 23(5), 599-622.

Hartman, J. L. \& Mc Cambridge, J. (2011). Optimizing millennials' communication styles. Business Communication Quarterly, 74(1), 22-44.

Heeks, R. \& Stanforth, C. (2015). Technological change in developing countries: opening the black box of process using actor-network theory. Development Studies Research, 2(1), 33-50. doi:10.1080/ 21665095.2015.1026610

Hillman, D. R. (2014). Understanding multigenerational work-value conflict resolution. Journal of Workplace Behavioral Health, 29(3), 240-257. doi:10.1080/15555240.2014.933961

Hirschi, A., Freund, P. A. \& Herrmann, A. (2014). The career engagement scale: development and validation of a measure of proactive career behaviors. Journal of Career Assessment, 22(4), 575-594.

Holian, R. (2015). Work, career, age and life-stage: assumptions and preferences of a multigenerational workforce. Labour \& Industry: a Journal of the Social and Economic Relations of Work, 25(4), 278-292.

ICT Specialists in Employment (2017). Eurostat. Retrieved from https://ec.europa.eu/eurostat/statisticsexplained/index.php/ICT_specialists_in_employment

Immordino-Yang, M. H., Christodoulou, J. A. \& Singh, V. (2012). Rest is not idleness: Implications of the brain's default mode for human development and education. Perspectives on Psychological Science, 7(4), 352364. doi:10.1177/1745691612447308

Information Technologies in Lithuania (2018). Lithuanian Department of Statistics. Retrieved from https://ivpk.Irv.It/uploads/ivpk/documents/files/Informacines\%20technologijos\%20Lietuvoje_2018.pdf

Jones, J. S., Murray, S. R. \& Tapp, S. R. (2018). Generational differences in the workplace. The Journal of Business Diversity, 18(2), 88-97.

Kardelis, K. (2007). Moksliniu tyrimy metodologija ir metodai [Research methodology and methods]. Šiauliai, Lithuania: Mokslo ir enciklopedijų leidybos centras.

Kirk, S. (2016). Career capital in global Kaleidoscope Careers: the role of HRM. The International Journal of Human Resource Management, 27(6), 681-697.

Kong, H., Wang, S. \& Fu, X. (2015). Meeting career expectation: can it enhance job satisfaction of Generation Y? International Journal of Contemporary Hospitality Management, 27(1), 147-168. doi:10.1108/IJCHM-082013-0353

Kultalahti, S. \& Viitala, R. (2015). Generation Y-challenging clients for HRM? Journal of Managerial Psychology, 30(1), 101-114. doi:10.1108/JMP-08-2014-0230

Lepojevic, V., Djordjevic, B. \& Ivanovic-Djukic, M. (2018). Mediating effects of career stage on job-related characteristics-job satisfaction relationship. Engineering Economics, 29(2), 215-225. doi:10.5755/ j01.ee.29.2.18637

Lepold, A., Tanzer, N., Bregenzer, A. \& Jiménez, P. (2018). The efficient measurement of job satisfaction: facetitems versus facet scales. International Journal of Environmental Research and Public Health, 15(7), 1362. doi:10.3390/ijerph15071362

Mainiero, L. A. \& Sullivan, S. E. (2011). Kaleidoscope careers: an alternate explanation for the "opt-out" revolution. Academy of Management Perspectives, 19(1), 106-123. doi:10.5465/ame.2005.15841962 
Statnicke, G., Savaneviciene, A. \& Sakys, I. (2019). Career engagement of different generations: A case study in the information and communication technology (ICT) sector in Lithuania. New Trends and Issues Proceedings on Humanities and Social Sciences. [Online]. 6(2), pp 37-49. Available from: www.prosoc.eu

Miller, J. D. (2011). Active, balanced, and happy: these young Americans are not bowling alone. The Generation $X$ Report, 1(1), 1-8.

Naim, M. F. \& Lenka, U. (2018). Development and retention of Generation Y employees: a conceptual framework. Employee Relations, 40(2), 433-455.

Ng, E. S., Lyons, S. T. \& Schweitzer, L. (2018). Generational career shifts: how matures, boomers, Gen Xers, and millennials view work. Bringley, UK: Emerald Publishing Limited.

Regulation (EC) No. 251/2009 of the Commission of the European Communities (2009). The Commission of the European Communities. Retrieved from https://eur-lex.europa.eu/legal-content/LT/TXT/ ?uri=CELEX:32009R0251

Rentz, K. C. (2015). Beyond the generational stereotypes: a study of US Generation Y employees in context. Business and Professional Communication Quarterly, 78(2), 136-166.

Robbins, S. P. (2002). The truth about managing people and nothing but the truth. Upper Saddle River, NJ: Prentice Hall.

Rudolph, C. W. \& Zacher, H. (2018). The kids are alright: Taking stock of generational differences at work. The Industrial-Organizational Psychologist, 55(3), 1-7. doi:10.31234/osf.io/wbsh5

Schullery, N. M. (2013). Workplace engagement and generational differences in values. Business Communication Quarterly, 76(2), 252-265. doi:10.1177/1080569913476543

Stanimir, A. (2015). Generation Y-characteristics of attitudes on labour market. Mediterranean Journal of Social Sciences, 6(2 S5), 22. doi:10.5901/mjss.2015.v6n2s5p22

Sullivan, S. E., Forret, M. L., Carraher, S. M. \& Mainiero, L. A. (2009). Using the kaleidoscope career model to examine generational differences in work attitudes. Career Development International, 14(3), 284-302.

Tapscott, D. (2009). Growing up digital: how the net generation is changing your world. New York, NY: McGrawHill.

Teng, L. S., Jayasingam, S. \& Zain, K. N. M. (2018). Debunking the myth of money as motivator in a multigenerational workforce. Pertanika Journal of Social Sciences \& Humanities, 26(1), 129-148.

Tulgan, B. (2009). Not everyone gets a trophy: How to manage generation Y. Hoboken, NJ: John Wiley \& Sons.

Twenge, J. M. (2010). A review of the empirical evidence on generational differences in work attitudes. Journal of Business and Psychology, 25(2), 201-210. doi:10.1007/s10869-010-9165-6

Twenge, J. M., Campbell, S. M., Hoffman, B. J. \& Lance, C. E. (2010). Generational differences in work values: leisure and extrinsic values increasing, social and intrinsic values decreasing. Journal of Management, 36(5), 1117-1142. doi:10.1177/0149206309352246

Valentine, B.D. \& L. Powers, T. (2013). Generation Y values and lifestyle segments. Journal of Consumer Marketing, 30(7), 597-606.

Vondracek, F. W., Lerner, R. M. \& Schulenberg, J. E. (2018). Career development: a life-span developmental approach. Abingdon, UK: Routledge. doi:10.4324/9781315792705

Westerman, J. W. \& Yamamura, J. H. (2007). Generational preferences for work environment fit: effects on employee outcomes. Career Development International, 12(2), 150-161. doi:10.1108/ 13620430710733631

Wilson, B., Squires, M., Widger, K., Cranley, L. \& Tourangeau, A. (2008). Job satisfaction among a multigenerational nursing workforce. Journal of Nursing Management, 16(6), 716-723. doi:10.1111/ j.1365-2834.2008.00874.x

Zhang, T., Abound Omran, B. \& Cobanoglu, C. (2017). Generation Y's positive and negative eWOM: use of social media and mobile technology. International Journal of Contemporary Hospitality Management, 29(2), 732-761. doi:10.1108/IJCHM-10-2015-0611

Zhang, T., Lu, C. \& Kizildag, M. (2017). Engaging generation $Y$ to co-create through mobile technology. International Journal of Electronic Commerce, 21(4), 489-516. doi:10.1080/10864415.2016.1355639 